\author{
Marcin Gołembski* \\ Henryk Sobolewski**
}

\title{
METODY MIERZENIA EFEKTÓW REALIZACJI FUNKCJI PERSONALNEJ WE WSPÓŁCZESNYCH PRZEDSIĘBIORSTWACH
}

\section{WPROWADZENIE}

Postępująca globalizacja, coraz bardziej turbulentne otoczenie oraz nasilająca się konkurencja, to już stałe elementy rzeczywistości gospodarczej. Ponadto, szeroko rozumiana grupa interesariuszy przedsiębiorstw wywiera presję na dążenie do ciagłego wzrostu długookresowej wartości firmy. Powyższe sprawia, że walka o zdobycie i utrzymanie przewagi konkurencyjnej, staje się coraz trudniejsza i obejmuje coraz więcej dziedzin funkcjonowania przedsiębiorstwa. Istotny wpływ na proces zarządzania firmą ma również, obserwowane aktualnie, spowolnienie gospodarcze o zasięgu światowym, które jest przyczyną nacisków na redukcję kosztów funkcjonowania, wzrost efektywności oraz optymalizację procesów w ramach wszystkich funkcji. Jedną z kluczowych funkcji przedsiębiorstwa, która przechodzi obecnie radykalne zmiany strukturalne i organizacyjne, jest funkcja personalna. Współcześnie, istotnym problemem działów personalnych i jedną z głównych przyczyn wspomnianych zmian, są ich niedostateczne kompetencje $\mathrm{w}$ zakresie porozumiewania się z pozostałymi działami funkcjonującymi $w$ ramach struktury organizacyjnej danego przedsiębiorstwa. Jest tak, ponieważ duża część pracowników działów HR (w tym sami dyrektorzy personalni) nie potrafią posługiwać się językiem biznesu, uniwersalnym i dla wszystkich zrozumiałym językiem liczb. Zarządy firm oczekują odpowiedzi na pytania o stopę zwrotu $\mathrm{z}$ poniesionych inwestycji oraz ujęte $\mathrm{w}$ weryfikowalnej formie

* Doktor, Adiunkt w Katedrze Zarządzania i Analizy Zasobów Przedsiębiorstwa, Uniwersytet Ekonomiczny w Poznaniu.

** Prof. zw. dr hab., Kierownik Katedry Zarządzania i Analizy Zasobów Przedsiębiorstwa, Uniwersytet Ekonomiczny w Poznaniu. 
efekty działań, realizowanych w ramach procesów kadrowych ${ }^{1}$. Dlatego, nawiązując do stwierdzenia P. Druckera - „nie mierzysz, nie zarządzasz”, ${ }^{2}$, jednym z kluczowych wyzwań stojących przed menedżerami, jest problem parametryzacji funkcji personalnej.

Wobec powyższego, celem niniejszego opracowania jest ukazanie znaczenia mierzenia efektów realizacji procesów kadrowych w zarządzaniu funkcją personalną we współczesnych przedsiębiorstwach. W części empirycznej artykułu, zaprezentowano wyniki badań, w których wykorzystano źródła wtórne, oraz cząstkowe wyniki badań pierwotnych, przeprowadzonych na zbiorowości 50 przedsiębiorstw, przy wykorzystaniu kwestionariusza ankiety oraz wywiadów bezpośrednich.

\section{DYSFUNKCJE W ZARZĄDZANIU PROCESAMI KADROWYMI W ŚWIETLE LITERATURY}

Celem systematyzacji pojęć, zdefiniować należy kluczowe z perspektywy niniejszego tekstu pojęcie funkcji personalnej. Zdaniem Z. Antczaka funkcja personalna obejmuje ogół działań związanych z funkcjonowaniem ludzi w organizacji. W jej zakres wchodzą czynności o charakterze wykonawczym, doradczym i regulacyjnym. W teorii i praktyce występują też inne bliskoznaczne terminy, za pomocą których poszczególni autorzy opisują określone procesy, składniki lub problemy $\mathrm{w}$ ramach szeroko rozumianej funkcji personalnej, m. in.: administrowanie, kierowanie, zarządzanie personelem, kadrami, zasobami ludzkimi, potencjałem ludzkim, kapitałem ludzkim ${ }^{3}$. Kształt funkcji personalnej w konkretnej organizacji powstaje w wyniku oddziaływania wielu czynników, takich jak strategia firmy, jej struktura i kultura organizacyjna oraz pod wpływem określonych relacji podmiotów zewnętrznych i wewnętrznych ${ }^{4}$. Nawiązując do zaprezentowanej definicji, właśnie relacje wewnętrzne stanowią podstawową przesłankę zmian w strukturze i organizacji funkcji personalnej we współczesnych organizacjach. Z badań wynika, iż mimo tego, że zarówno teoretycy, jak i praktycy zarządzania zgadzają się co do strategicznej roli zasobów ludzkich w osiaganiu przewagi konkurencyjnej, to jednak, szczególnie praktycy, krytycznie odnoszą się do realizacji funkcji personalnej w przedsiębiorstwach, czyli inaczej mówiąc do efektów pracy działów personalnych. Z $\mathrm{Z}$ przeprowadzo-

${ }^{1}$ P. Dziechciarz, Pomiar efektywności polityki personalnej, „Zarządzanie Zasobami Ludzkimi” 2011, nr 3-4, Instytut Pracy i Spraw Socjalnych, Warszawa 2011, s. 161.

${ }^{2}$ P. D r u c k e r, Innovate or die: Drucker on financial services, „The Economist” 1999, September 25 .

${ }^{3} \mathrm{Z}$. Antc zak, Funkcja personalna $w$ przedsiębiorstwie $w$ okresie transformacji społecznogospodarczej w Polsce, Wydawnictwo AE we Wrocławiu, Wrocław 2005, s. 18.

${ }^{4} \mathrm{H}$. Król, A. Ludwi c zyńs ki (red.), Zarzqdzanie zasobami ludzkimi. Tworzenie kapitału ludzkiego organizacji, PWN, Warszawa 2006, s. 34. 
nego przez Hewitt Associates badania „Barometr HR 2012”, wynikało, że prawdziwe oczekiwania i potrzeby biznesu nie znajdują odzwierciedlenia w działaniach HR. W 2007 r. Benefactor, Gazeta Praca i PSZK przeprowadziły badanie „Barometr HR", , w którym częstymi odpowiedziami były stwierdzenia, że pracownicy działów HR nie zajmuja się tym, czym powinni, Pracownicy działów HR ocenili swoja prace dość nisko. (...) Jednak reprezentanci innych działów byli jeszcze bardziej krytyczni, a także (...) dziat HR nie wnosi do firmy żadnej wartości, a wręcz przeciwnie - jest tylko źródtem niepotrzebnych kosztów ${ }^{7}$.

Tabela 1

Dysfunkcje „tradycyjnego” modelu funkcji personalnej

\begin{tabular}{|c|c|}
\hline Dysfunkcja & Skutek \\
\hline \hline Brak włączania kierowników & - rozproszenie odpowiedzialności za decyzje pomiędzy dział \\
liniowych w realizację zadań & personalny i kierownictwo liniowe \\
w ramach funkcji personalnej & - wydłużanie się procesu decyzyjnego \\
w poszczególnych jednostkach & - niewystarczająca wiedza specjalistów HR dotycząca potrzeb \\
biznesu & i problemów danej jednostki biznesu, spowodowana bra- \\
& kiem uczestnictwa w procesie realizacji zadań \\
\hline Brak standaryzacji (informatyza- & - brak warunków dla specjalistów HR do skupienia wysiłków \\
cji) i delegowania rutynowych & na kwestiach strategicznych, kreujących wartość dla organi- \\
procesów i zadań z obszaru & zacji \\
HR & - wysokie koszty funkcjonowania działów personalnych \\
\hline Brak mierzenia efektywności & - brak akceptacji i zrozumienia dla działań HR, ze względu \\
działań w ramach realizacji & na brak możliwości zmierzenia efektów natury ilościowej \\
funkcji personalnej & i jakościowej \\
& - brak możliwości oszacowania relacji pomiędzy produktyw- \\
& nością, konkurencyjnością a inwestycjami w działania HR \\
\hline
\end{tabular}

Źródło: opracowanie własne na podstawie: A. B aron, M. Armstrong, Zarzqdzanie kapitatem ludzkim. Uzyskiwanie wartości dodanej dzięki ludziom, Wolters Kluwer business, Kraków 2008, s. 145-160; P. Re illy, T. W illi a m s, Strategiczne Zarzqdzanie zasobami ludzkimi. Rozwijanie potencjału organizacji dzięki funkcji personalnej, Wolters Kluwer business, Kraków 2009, s. 46 i nast.

${ }^{5}$ Uczestnikami badania byli dyrektorzy działów personalnych oraz członkowie zarządu HR, przedstawiciele wiodących firm w Europie. W badaniu uczestniczyły 52 firmy, z których $62 \%$ to firmy notowane na giełdzie. Łącznie zatrudniają one 2,4 mln. pracowników i osiagają dochody przekraczające 517 miliardów euro. Badanie prowadzone jest od 2005 r., a jego głównym celem jest śledzenie zmian w postrzeganiu roli HR w organizacji i pokazywanie kluczowych aspektów, które mają wpływ na efektywność działań podejmowanych przez działy HR.

http://www.portfel.pl/pl/gospodarka/artykul/1/13734/Wyniki_Badania_Barometr_HR_2012, data dostępu: 27.02.2013.

${ }^{6}$ Badanie przeprowadzone zostało $\mathrm{w}$ formie ankiety internetowej. Jej adresatami byli pracownicy działów HR i działów z nimi współpracujących. Skierowane zostało bezpośrednio do osób, które zarejestrowane są w bazach danych organizatorów badania. Ankietę wypełniło 476 osób, w tym 337 z nich to pracownicy działów HR, a 139 - pozostałych działów.

${ }^{7}$ P. Dziechciarz, op. cit., s. 163. 
Zastanawiając się nad przyczynami tak stanowczych sądów na temat realizacji funkcji personalnej, wysnuć można wniosek, że działy personalne funkcjonują niejednokrotnie „obok” biznesu, nie wpisując się swoim działaniem w potrzeby menedżerów liniowych. Na podstawie studiów literaturowych wskazać można dysfunkcje w realizacji funkcji personalnej opartej o ,tradycyjny” scentralizowany dział HR. W zamieszczonej tab. 1 ujęto dysfunkcje wybrane, uznane przez autorów za najistotniejsze.

Analizując omówione dysfunkcje, szczególną uwagę zwrócić należy na problem mierzenia efektów realizacji funkcji personalnej, gdyż właśnie na tym polu widać wyraźną lukę pomiędzy aktywnością działów personalnych a oczekiwaniami zarządzających przedsiębiorstwami. Z badań przeprowadzonych przez jedną z wiodących firm doradczych Deloitte wynika $^{8}$, że pomiar funkcji personalnej jest jednym z kluczowych przyczyn marginalizacji znaczenia działów HR w przedsiębiorstwach w opinii zarządzających. Jest tak ze względu na trudności z wyrażaniem efektów podejmowanych przez działy personalne działań, w formie liczb i wskaźników mogących stanowić podstawę podejmowania decyzji.

Tabela 2

Narzędzia mierzenia efektywności realizacji funkcji personalnej w badanych przedsiębiorstwach

\begin{tabular}{|l|c|}
\hline Narzędzie mierzenia efektywności funkcji HR & Przedsiębiorstwa stosujące narzędzie \\
\hline \hline $\begin{array}{c}\text { KPI (Key Performance Indicators) } \\
\text { cji dla funk- }\end{array}$ & $25 \%$ \\
\hline $\begin{array}{c}\text { Pomiar efektywnej } \\
\text { kadrowych }\end{array}$ & $36 \%$ \\
\hline Optymalizacja procesów kadrowych realizacji procesów & $12 \%$ \\
\hline $\begin{array}{l}\text { Benchmarking efektywności procesów ka- } \\
\text { drowych }\end{array}$ & $10 \%$ \\
\hline Pomiar zwrotu inwestycji w kapitał ludzki & $6 \%$ \\
\hline
\end{tabular}

Źród ło: wyniki badania „Trendy HRM 2011” Deloitte.

8 „Trendy HRM 2011” - Badanie zostało przeprowadzone od czerwca do lipca 2011 na grupie grona dyrektorów i profesjonalistów HR wiodących firm działających w Polsce. Badanie zostało przeprowadzone w formie elektronicznej ankiety. W badaniu udział wzięły 254 firmy, szerzej, zob. w: P. B e rło w s k i, Daleko od strategii, „Personel i zarządzanie” 2011, nr 11, s. 28-31.

${ }^{9}$ Wskaźniki wydajności lub zaawansowania prac, stosowane jako mierniki procesu dążącego do osiagnięcia celów organizacji. Są one używane jako narzędzie kontroli w firmie do sprawdzania stopnia realizacji zaplanowanego celu. Ich rola jest kwantyfikacja stanu wybranego elementu w projekcie tak, aby można było ocenić postęp i podjąć ewentualną korektę. KPI są definiowane zgodnie ze strategią organizacji. Dzięki nim można sprawdzać nie tylko wykonywanie celów finansowych, ale również takich celów, jak utrzymanie bądź osiągnięcie pewnego poziomu jakości produktu, usług, relacji między pracownikami, czy skuteczność wprowadzonych zmian bądź zasad organizacyjnych. 
Znamiennym podsumowaniem badania przeprowadzonego przez Deloitte jest konkluzja, że jedynie $22 \%$ działów HR w badanych organizacjach faktycznie odgrywa strategiczną rolę $\mathrm{w}$ firmie ${ }^{10}$.

Odnosząc się do powyższego, tradycyjne rozwiązania w zakresie struktury i organizacji funkcji personalnej nie sprawdzają się we współczesnym otoczeniu biznesowym. Chcąc podnieść efektywność funkcji personalnej, osoby odpowiedzialne za jej realizację zmuszone są do zmiany architektury procesów w ramach funkcji HR. Na podstawie dotychczasowych rozważań sformułować można wnioski dotyczące kierunków rozwoju funkcji personalnej w przedsiębiorstwach, chcących skutecznie konkurować we współczesnym, turbulentnym i wysoce konkurencyjnym otoczeniu:

- działy personalne powinny dążyć do realizacji zadań „bliżej biznesu”. W praktyce oznacza to organizacyjną decentralizację (fragmentacje) funkcji personalnej celem lepszego rozpoznania potrzeb poszczególnych jednostek biznesu, oraz kompresji procesów decyzyjnych;

- standaryzacja, informatyzacja, delegowanie do menedżerów liniowych, lub/i outsourcing rutynowych zadań w ramach funkcji personalnej (ewidencje, nadzorowanie przebiegu pracy, wynagrodzenia, analizy efektywności i kosztów pracy, szkolenia itp.) tak, aby komórki personalne mogły skupić swoje działania na kwestiach strategicznych, których realizacja przyczynia się do tworzenia wartości;

- kładzenie nacisku na zarządzanie i monitorowanie efektywności obszaru zarządzania zasobami ludzkimi. Wymusza to konieczność stosowania przez działy personalne uniwersalnego języka biznesu, czyli języka liczb, wskaźników, ryzyka itp ${ }^{11}$.

Przedmiot rozważań i przyjęty cel niniejszego opracowania sprawia, iż spośród wymienionych wyżej kierunków rozwoju funkcji personalnej, na szczególną uwagę zasługuje kwestia monitorowania efektów przebiegu procesów kadrowych. W związku z powyższym, w dalszej części tekstu, dokonana zostanie próba identyfikacji i systematyzacji mierników funkcji personalnej.

\section{IDENTYFIKACJA I KLASYFIKACJA METOD I NARZĘDZI MIERZENIA EFEKTÓW REALIZACJI FUNKCJI PERSONALNEJ}

Jak wspomniano we wstępie, stwierdzenie „nie mierzysz, nie zarządzasz” ma zastosowanie w odniesieniu do niemal wszystkich funkcji przedsiębiorstwa. Ujmowanie efektów działań i podejmowanych decyzji w formie liczb i wskaźników, jest na stałe wpisane $\mathrm{w}$ realizację takich procesów przebiegających

${ }^{10}$ P. B erłowski, op. cit., s. 31.

${ }^{11}$ A. Canning s, T. Hills, A framework for auditing HR: Strengthening the role of HR in the organisation, „Industrial and Commercial Training” 2012, Vol. 44, Iss: 3, s. 139-149. 
w przedsiębiorstwach jak: zarządzanie finansami, produkcja, sprzedaż, logistyka, czy marketing. W tym świetle, za zaskakujący należy uznać fakt, iż zagadnienia związane z mierzeniem efektów realizacji procesów kadrowych, w dalszym ciagu są niedostatecznie rozpoznane na gruncie literatury oraz traktowane jako trudne wyzwanie dla menedżerów w praktyce gospodarczej ${ }^{12}$.

Stąd, pojawia się potrzeba dokonania próby identyfikacji i klasyfikacji najważniejszych grup mierników, parametryzujących przebieg procesów kadrowych. Na zamieszczonym poniżej schemacie przedstawiono propozycję podziału mierników funkcji personalnej.

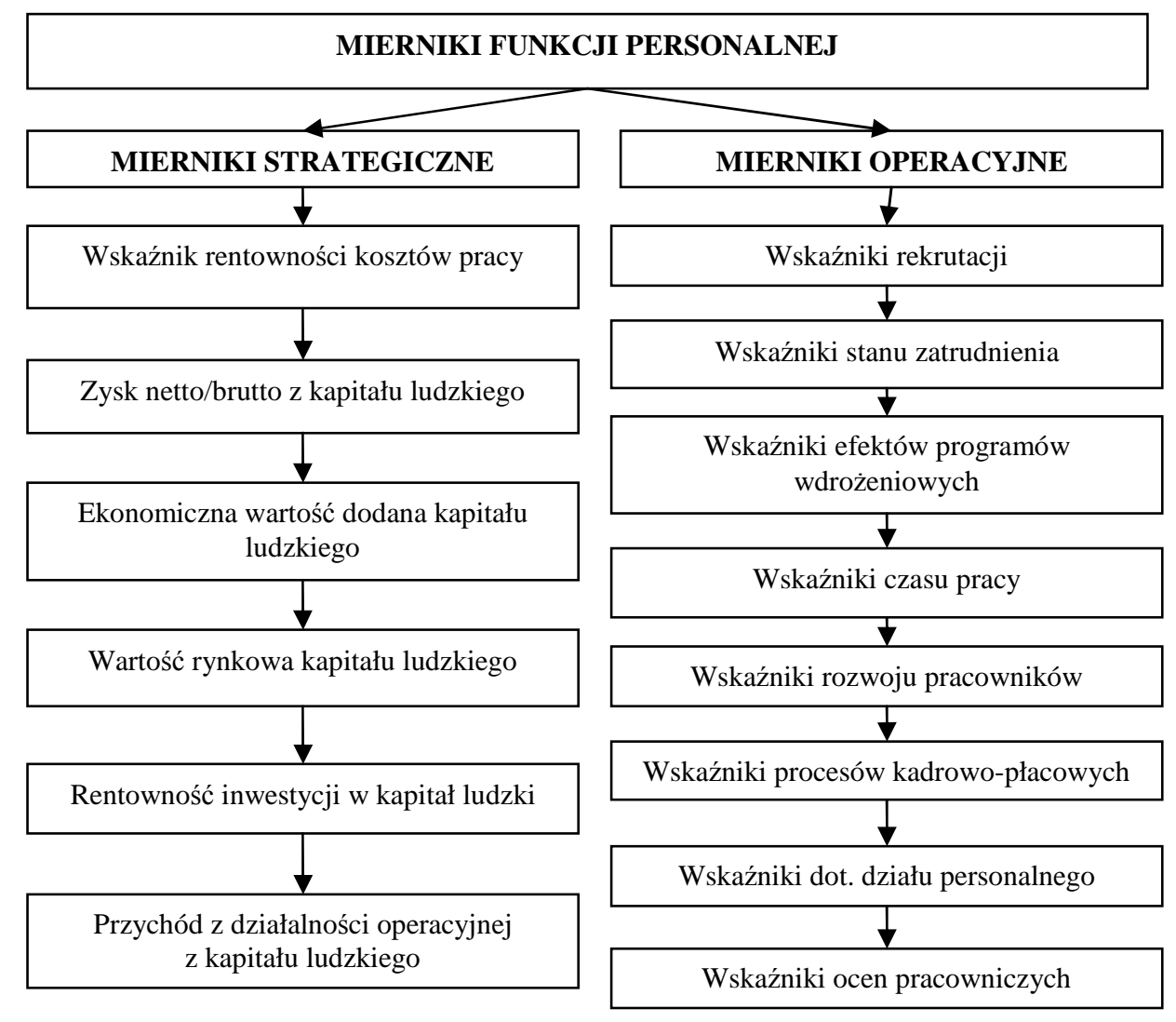

Rys. 1. Klasyfikacja mierników realizacji funkcji personalnej

Źródło: opracowanie własne na podstawie: Ch. A s h to n, M. Haffenden, A. La mbert, The ,fit for purpose” HR function, „Strategic HR Review” 2004, Vol. 4, Iss: 1, s. 32-35.

${ }^{12}$ A. W ar d, Ac-Count-able HR, ,Human Resource Management International Digest” 2008, Vol. 16, Iss: 3, s. 11-13. 
Strategiczne mierniki efektów zarządzania zasobami ludzkimi

\begin{tabular}{|c|c|}
\hline Wskaźnik & Interpretacja wskaźnika \\
\hline $\begin{array}{l}\text { PRZYCHODY - KOSZTY - CALKOWITY KOSZT } \\
\text { KAPITALU LUDZKIEGO } \\
\text { CALKOWITY KOSZT KAPITALU LUDZKIEGO }\end{array}$ & $\begin{array}{l}\text { Rentowność inwestycji w kapitał ludzki - wskaźnik } \\
\text { pozwala na oszacowanie ile z każdej zainwestowanej } \\
\text { w pracownika ,złotówki”, przynosi on zysku dla } \\
\text { firmy. }\end{array}$ \\
\hline $\begin{array}{l}\text { ZYSK NETTO PO OPODATKOWANIU - KOSZT } \\
\text { KAPITALU }\end{array}$ & \multirow[t]{2}{*}{$\begin{array}{l}\text { Ekonomiczna wartość dodana kapitału ludzkiego - } \\
\text { wskaźnik ten wskazuje rzeczywisty zysk na etat. }\end{array}$} \\
\hline ZBA PRA & \\
\hline WARTOŚĆ RYNKOWA - WARTOŚĆ KSIĘGOWA & $\begin{array}{l}\text { Wskaźnik pozwala szacunkowo obliczyć wartość } \\
\text { rynkową kapitału ludzkiego (wskaźnik obarczony jes } \\
\text { dużym marginesem błędu, gdyż wartość rynkowa jes } \\
\text { dynamiczna) }\end{array}$ \\
\hline
\end{tabular}

Źródło: opracowanie własne na podstawie: S. Miranda, Creating the indispensable HR function, ,Strategic HR Review” 2005, Vol. 4, Iss: 3, s. 32-35.

Operacyjne (wybrane, przykładowe) wskaźniki realizacji funkcji personalnej

\begin{tabular}{|c|c|}
\hline Wskaźnik & Interpretacja wskaźnika \\
\hline $\begin{array}{l}\text { LICZBA PRZEPROWADZONYCH ROZMÓW } \\
\text { KWALIFIKACYJNYCH }\end{array}$ & \multirow{2}{*}{$\begin{array}{l}\text { Wskaźnik pokazujący wydajność procesów rekruta- } \\
\text { cyjnych - wydajność procesu można liczyć całościo- } \\
\text { wo, lub w przeliczeniu na jedną osobę rekrutującą. }\end{array}$} \\
\hline LICZBA PRZYJĘTYCH PRACOWNIKÓW & \\
\hline $\begin{array}{l}\text { LICZBA PRACOWNIKÓW ZE STAŻEM PONIŻEJ } \\
\qquad 2 \text { LAT }\end{array}$ & \multirow{2}{*}{$\begin{array}{l}\text { Tzw. wskaźnik „młodych” - w tej grupie jest zazwy- } \\
\text { czaj wyższa płynność personelu, jej członkowie są też } \\
\text { generalnie mniej wydajni, ze względu na krótki staż } \\
\text { pracy. Wysoka wartość wskaźnika może sugerować } \\
\text { zagrożenie stabilności kompetencji oraz struktury } \\
\text { wewnętrznej organizacji }\end{array}$} \\
\hline LICZBA PRACOWNIKÓW OGÓŁEM & \\
\hline $\begin{array}{l}\text { Grupa wskaźników mierzących wy- } \\
\text { dajność działów personalnych jak np. } \\
\text { koszty działu HR / koszty operacyjne; } \\
\text { zatrudnieni w dziale HR / wszyscy } \\
\text { pracownicy; koszty działu HR / kosz- } \\
\text { ty kontraktów zewnętrznych. }\end{array}$ & $\begin{array}{l}\text { Wdrożenie parametryzacji funkcji personalnej pozwa- } \\
\text { la na ustalenie m. in.: udziału kosztów działu HR } \\
\text { w kosztach operacyjnych, współczynnika obciążenia } \\
\text { działu HR, wskaźnika wydelegowania funkcji kadro- } \\
\text { wej itp. }\end{array}$ \\
\hline
\end{tabular}

Źródło: opracowanie własne na podstawie: N. J. Hig gi n s, Putting Lean HR into practice, „Strategic HR Review” 2007, Vol. 6, Iss: 4, s. 16-19; A. W ard, Ac-Count-able HR, „Human Resource Management International Digest” 2008, Vol. 16, Iss: 3, s. 11-13. 
Klasyfikacja mierników funkcji personalnej zakładająca ich podział na mierniki strategiczne i operacyjne, podyktowana jest wyraźną różnicą pomiędzy podmiotami parametryzacji oraz zasięgiem oddziaływania danego wskaźnika w procesie podejmowania decyzji. Wskaźniki strategiczne pokazują efekty całościowe procesu zarządzania zasobami ludzkimi. Wskaźniki operacyjne natomiast, weryfikują sposób realizacji i efekty przebiegu procesów kadrowych, a tym samym stanowią dogodny punkt wyjścia przy ocenie funkcjonowania służb personalnych. Ze względu na ograniczenia objętościowe niniejszego opracowania, nie jest możliwe omówienie wszystkich wskaźników w ramach każdej z przedstawionych na rys. 1 grup. Dlatego też, w dalszej części tekstu, w tabelarycznej formie przybliżono wybrane, przykładowe wskaźniki, zarówno te strategiczne, jak i operacyjne, które pozwalają na weryfikację efektów realizacji funkcji personalnej.

Analizując powyższą klasyfikację i interpretację wskaźników mierzących efekty realizacji funkcji personalnej, stwierdzić należy, że mimo jakościowego charakteru niektórych procesów kadrowych (np. rozwój pracowników, programy wdrożeniowe itp.), niemalże wszystkie z nich mogą być z powodzeniem mierzone, a tym samym lepiej zarządzane. Jednakże praktyka pokazuje, że mimo rosnącej świadomości menedżerów, dotyczącej znaczenia mierzenia efektów funkcji personalnej $\mathrm{w}$ procesach optymalizacji i podnoszenia efektywności, w praktyce tylko niewielki odsetek przedsiębiorstw stosuje systemowe podejście do mierzenia efektów procesów kadrowych. Powyższe znajduje potwierdzenie w wynikach badań, które będą przedmiotem rozważań w części empirycznej artykułu.

\section{DOŚWIADCZENIA PRZEDSIĘBIORSTW W ZAKRESIE STOSOWANIA POMIARÓW PROCESÓW KADROWYCH - WYNIKI BADAŃ}

W empirycznej części niniejszego opracowania, zaprezentowano cząstkowe wyniki pilotażowego projektu badawczego, którego celem było ustalenie stanu faktycznego w zakresie stosowania mierników funkcji personalnej oraz zbadania stopnia świadomości menedżerów, dotyczącej miejsca i roli parametryzacji procesów kadrowych w zarządzaniu firmą. Badanie przeprowadzono na próbie 50 celowo dobranych przedsiębiorstw prywatnych. Wiodącym narzędziem badawczym, był kwestionariusz ankiety, a narzędziem uzupełniającym, były wywiady bezpośrednie. Liczebność próby badawczej oraz stan zaawansowania badań, nie pozwala na formułowanie wniosków o charakterze ogólnym, stwarza jednak możliwość nakreślenia problemu oraz wskazuje możliwe i pożądane kierunki dalszych badań. 
I tak, w pierwszej kolejności zbadano poziom świadomości respondentów dotyczącej potrzeby stosowania pomiarów efektów realizacji funkcji personalnej. Wyniki w formie graficznej ujęto na rys. 1.

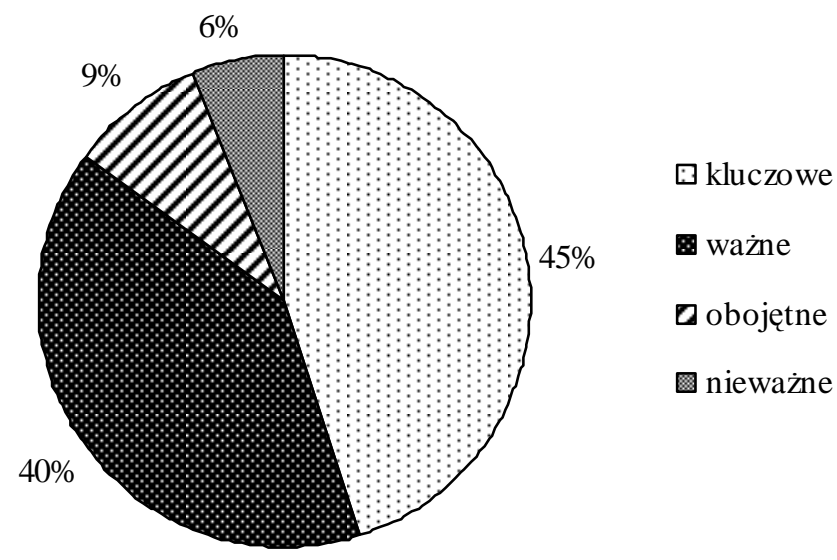

Rys. 1. Znaczenie pomiarów procesów kadrowych w zarządzaniu przedsiębiorstwem Źródło: opracowanie własne na podstawie przeprowadzonych badań.

Godnym odnotowania faktem, jest wysoki poziom świadomości badanych na temat poziomu istotności pomiarów funkcji personalnej w procesie zarządzania firmą. Zdecydowana większość (85\%) badanych uznała, że stosowanie omawianych rozwiązań jest zadaniem ważnym (40\%), a wręcz kluczowym $(45 \%)$ z perspektywy organizacji. Jednakże w toku dalszych badań, zaobserwowano zaskakujący paradoks. Otóż, mimo tak wysokiej świadomości, tylko 5\% badanych deklarowało stosowanie pomiarów funkcji personalnej w sposób systemowy, a zaledwie $10 \%$ stosuje tylko nieliczne wskaźniki, w sposób akcyjny i nie do końca skoordynowany. Natomiast, aż 83\% badanych przedsiębiorstw w ogóle nie stosuje żadnych pomiarów w odniesieniu do procesów kadrowych (rys. 2).

Powyższe zdaje się dowodzić, że z jednej strony zarządzający zdają sobie sprawę z problemu braku możliwości pomiaru procesów kadrowych, z drugiej strony natomiast, brakuje im wiedzy i kompetentnych pracowników, którzy wzięliby na siebie obowiązek wdrożenia systemowego podejścia do parametryzacji funkcji personalnej. Wiedza i doświadczenie stanowią, bowiem kluczowe uwarunkowania stosowania wspomnianych pomiarów $\mathrm{w}$ procesie zarządzania. Postawioną tezę zdają się potwierdzać wyniki badania (rys. 3), zgodnie, z którymi spośród niewielkiego odsetka przedsiębiorstw, które mierzą efekty realizacji funkcji personalnej, zdecydowana większość to międzynarodowe korporacje. 


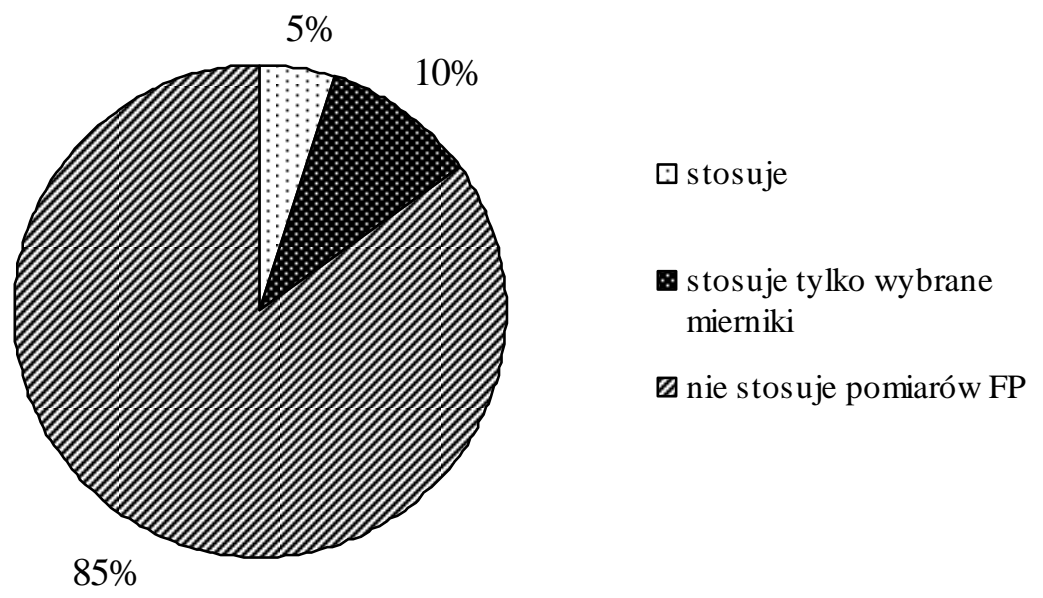

Rys. 2. Stosowanie mierników procesów kadrowych Źródło: jak do rys. 1.

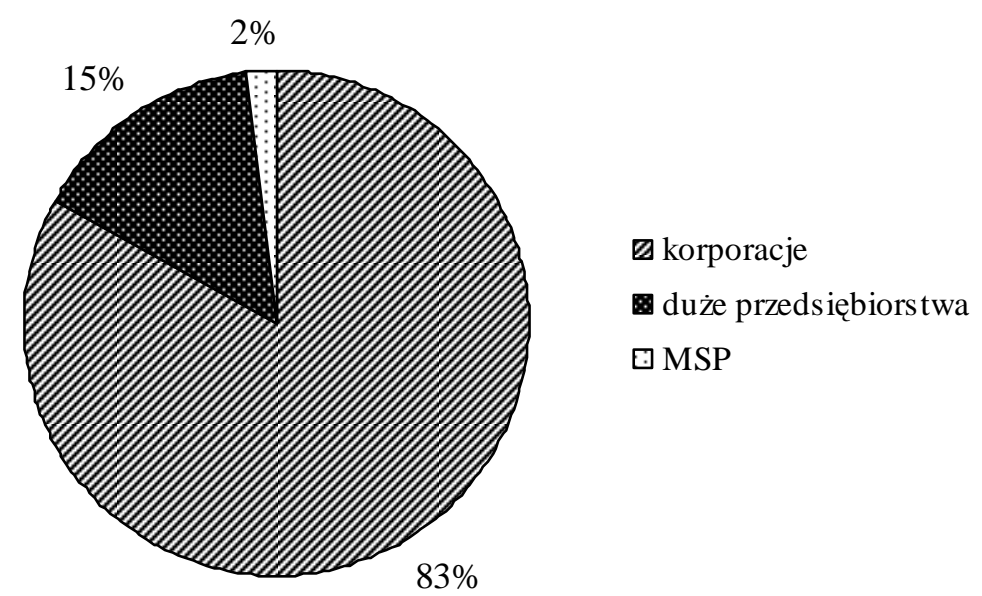

Rys. 3. Stosowanie pomiarów funkcji personalnej a wielkość przedsiębiorstwa Źródło: jak do rys. 1.

Należy przypuszczać, iż taki stan rzeczy wynika z dobrze zorganizowanego w dużych korporacjach trans granicznego transferu wiedzy i metod zarządzania. Skutkuje to kopiowaniem najlepszych, sprawdzonych praktyk przez podmioty powiązane, co pozwala przypuszczać, że pomiary efektów realizacji funkcji personalnej, stanowią podstawę do zwiększania efektywności i wydajności procesów. 


\section{PODSUMOWANIE}

O ile strategiczne znaczenie zasobów ludzkich w organizacjach jest przedmiotem rozważań i dyskusji od bez mała trzydziestu lat ${ }^{13}$, o tyle rozwiązania w zakresie struktury, organizacji i pomiarów funkcji personalnej, które przyczyniają się do wdrażania w życie koncepcji strategicznego zarządzania zasobami ludzkimi i optymalizacji procesów zarządczych, są opisywane i stosowane w przedsiębiorstwach amerykańskich i zachodnioeuropejskich od około 5-6 lat. Natomiast na gruncie polskim, zarówno w teorii, jak i praktyce zarządzania, problematyka parametryzacji funkcji personalnej, w celu jej optymalizacji i ciągłego podnoszenia efektywności działania, w dalszym ciagu jest zagadnieniem niedostatecznie rozpoznanym. Dowodzą tego wyniki badań pilotażowych, które zaprezentowano w tekście (w szczególności rozdźwięk pomiędzy stanem świadomości, a praktyką stosowania mierników procesów kadrowych). Niniejszy artykuł stanowi przyczynek do dyskusji i dalszych pogłębionych badań nad efektywnością funkcji personalnej w przedsiębiorstwie.

\section{BIBLIOGRAFIA}

Antczak Z., Funkcja personalna $w$ przedsiębiorstwie $w$ okresie transformacji spoteczno - gospodarczej w Polsce, Wydawnictwo AE we Wrocławiu, Wrocław 2005.

Ashton Ch., Haffenden M., Lambert A., The "fit for purpose” HR function, „Strategic HR Review" 2004, Vol. 4, Iss: 1.

Baron A., Armstrong M., Zarzqdzanie kapitatem ludzkim. Uzyskiwanie wartości dodanej dzięki ludziom, Wolters Kluwer business, Kraków 2008.

B e rło w s ki P., Daleko od strategii, „Personel i zarządzanie” 2011, nr 11.

Cannings A., Hills T., A framework for auditing HR: Strengthening the role of HR in the organisation, „Industrial and Commercial Training” 2012, Vol. 44, Iss: 3.

D r u cker P., Innovate or die: Drucker on financial services, „The Economist” 1999, September 25.

D zi e ch c i a z P., Pomiar efektywności polityki personalnej, „Zarządzanie Zasobami Ludzkimi” 2011, nr 3-4, Instytut Pracy i Spraw Socjalnych, Warszawa 2011.

Hi g gi n s N. J., Putting Lean HR into practice, „Strategic HR Review” 2007, Vol. 6, Iss: 4.

Król H., Ludwiczyński A. (red.), Zarzqdzanie zasobami ludzkimi. Tworzenie kapitału ludzkiego organizacji, PWN, Warszawa 2006.

Li s tw an T. (red.), Zarzqdzanie kadrami, C. H. Beck, Warszawa 2010.

M ir and a S., Creating the indispensable HR function, „Strategic HR Review” 2005, Vol. 4, Iss: 3.

Reilly P., Williams T., Strategiczne Zarzqdzanie zasobami ludzkimi. Rozwijanie potencjatu organizacji dzięki funkcji personalnej, Wolters Kluwer business, Kraków 2009.

Ward A., Ac-Count-able HR, „Human Resource Management International Digest” 2007, Vol. 16, Iss: 3.

${ }^{13} \mathrm{~W}$ latach 80 . zaczęło wykształcać się strategiczne podejście do zasobów ludzkich, co nazwane zostało strategicznym zarządzaniem zasobami ludzkimi (Strategic Human Resources Management). Szerzej na ten temat Zob. w: T. Listwan (red.), Zarzqdzanie kadrami, C. H. Beck, Warszawa 2010, s.19-23. 
Marcin Gotembski,

Henryk Sobolewski

\section{METHODS OF MEASURING THE EFFECTS OF THE PERSONNEL FUNCTION IN MODERN ENTERPRISES}

Aim of this paper is to show the importance of measuring the effects of the implementation of HR processes management personnel function in modern enterprises. In the empirical part of the article presents the results of studies that used secondary sources, and the partial results of primary research carried out on the population 50 companies, using a questionnaire and direct interviews.

Key words: human resources management, personnel function, people management. 